\title{
Comovement of sales, retention practice and financing constraints in Dutch manufacturing
}

Citation for published version (APA):

Bruinshoofd, W. A., \& Letterie, W. A. (2001). Comovement of sales, retention practice and financing constraints in Dutch manufacturing. METEOR, Maastricht University School of Business and Economics. METEOR Research Memorandum No. 003 https://doi.org/10.26481/umamet.2001003

Document status and date:

Published: 01/01/2001

DOI:

10.26481/umamet.2001003

Document Version:

Publisher's PDF, also known as Version of record

\section{Please check the document version of this publication:}

- A submitted manuscript is the version of the article upon submission and before peer-review. There can be important differences between the submitted version and the official published version of record.

People interested in the research are advised to contact the author for the final version of the publication, or visit the DOI to the publisher's website.

- The final author version and the galley proof are versions of the publication after peer review.

- The final published version features the final layout of the paper including the volume, issue and page numbers.

Link to publication

\footnotetext{
General rights rights.

- You may freely distribute the URL identifying the publication in the public portal. please follow below link for the End User Agreement:

www.umlib.nl/taverne-license

Take down policy

If you believe that this document breaches copyright please contact us at:

repository@maastrichtuniversity.nl

providing details and we will investigate your claim.
}

Copyright and moral rights for the publications made accessible in the public portal are retained by the authors and/or other copyright owners and it is a condition of accessing publications that users recognise and abide by the legal requirements associated with these

- Users may download and print one copy of any publication from the public portal for the purpose of private study or research.

- You may not further distribute the material or use it for any profit-making activity or commercial gain

If the publication is distributed under the terms of Article $25 \mathrm{fa}$ of the Dutch Copyright Act, indicated by the "Taverne" license above, 


\title{
Comovement of Sales, Retention Practice
}

\section{and Financing Constraints in Dutch Manufacturing}

\author{
W. Allard Bruinshoofd ${ }^{\mathrm{a}, * *}$ \\ Wilko A. Letterie ${ }^{\mathrm{b}, * * *}$ \\ First draft, 28 February 2001 \\ ${ }^{a}$ Department of Economics - Maastricht University, Maastricht, the Netherlands. \\ ${ }^{b}$ BIRC, Center of Strategy Studies, Department of Strategy - Maastricht University, Maastricht, the Netherlands.
}

\begin{abstract}
We thank Martin Carree, Clemens Kool, Bas ter Weel and participants in BIRQ’s Q-seminar, the seminar on Investment Decisions by Firms, the MiMaMa colloquium and the seminar on Dutch Micro-Data Research for useful comments on earlier versions. Wilko Letterie acknowledges support by the PIONIER program of the Dutch Foundation for Scientific Research. The research is supported by a grant from the Maastricht Research School of Economics of Technology and Organizations (METEOR) and was partially carried out at the Center for Research of economic Micro-data (Cerem) of Statistics Netherlands. The views expressed are those of the authors and do not necessarily reflect policies of Statistics Netherlands. In addition, the usual disclaimer applies.

** Postal address: Department of Economics - Faculty of Economics and Business Administration Maastricht University, P.O.Box 616, 6200 MD Maastricht, the Netherlands. Phone: (0)43 388 2685. Fax: (0)43 388 4864. E-mail: a.bruinshoofd@algec.unimaas.nl.

*** $\quad$ Postal address: Department of Strategy - Faculty of Economics and Business Administration Maastricht University, P.O.Box 616, 6200 MD Maastricht, the Netherlands. Phone: (0)43 388 3645. Fax: (0)43 388 4893. E-mail: w.letterie@mw.unimaas.nl.
\end{abstract}




\title{
Comovement of Sales, Retention Practice
}

\section{and Financing Constraints in Dutch Manufacturing}

\author{
W. Allard Bruinshoofd \\ Wilko A. Letterie
}

\begin{abstract}
This paper assesses the significance of financing constraints in investment decisions for a balanced panel of 206 of the largest Dutch manufacturing firms over the period 1983-1996, employing split sample analysis of reduced form investment equations. Our empirical evidence demonstrates that financing constraints matter in Dutch manufacturing and are associated with high retention practice and strong firm-industry sales comovement.
\end{abstract}

Keywords: Investment, Financing constraints, Retention, Sales comovement Jel Classification: D2, L2, L6 


\section{Introduction}

Liquidation is costly. The exact cost of liquidation, however, depends on whom you can sell your assets to when you are forced to liquidate. Firms in the same line of business are the next best users of the assets. Hence, the liquidation cost is lowest when it is possible to sell the assets to a firm in the same business. If firm and industry sales are highly correlated, which by definition implies a high degree of comovement, then the firm and industry face declining demand at the same time and the liquidation value of assets is expected to be low. In that case other firms in the same line of business are likely to face difficulties in generating financial resources themselves to purchase the second-hand capital assets of their competitors or find no interest in expanding their business. Therefore, the probability that a firm is able to sell its assets to a firm in the same line of business - and hence the liquidation value of these assets - decreases with a higher degree of comovement of the firm and industry sales (cf. Shleifer and Vishny, 1992).

The contribution of this paper is that we investigate whether a firm's ability to finance investment depends on the degree of comovement of the firm and industry sales. The underlying idea is as follows. Debt capacity and the firm's ability to finance investment increases if the firm can provide collateral to a bank underlying a loan. Obviously the extent to which a firm can provide collateral depends on the liquidation value of the assets, which increases with better possibilities to resell the capital stock. Hence, it is likely that debt capacity increases with a high liquidation value and that the amount of collateralized loans such firms can generate tend to be higher. In line with Hubbard (1998) we regard these collateralized loans to be a close substitute of internal funds. Firms that are not able to resell their capital stock at favourable terms and therefore 
face low liquidation values are more likely to engage in uncollateralized loans. We expect that these firms are more likely to face financing constraints.

The empirical literature on corporate financing constraints has received substantial attention since the seminal contribution of Fazzari, Hubbard and Petersen (1988). The importance of financing constraints for investment decisions emerges from the fact that different sources of finance are differently priced. Well-known factors causing variation in the cost of funds are the presence of transaction costs, taxes and information problems, indicating that capital markets are incomplete and far from frictionless. The cost differences lead to a financing hierarchy for firms. In fact, it is hypothesized that managers of firms prefer funding investment with retained earnings over debt finance, and prefer debt over equity. An overview of the literature on the role of financing constraints is provided by Hubbard (1998).

This paper investigates the role of financing constraints in Dutch corporate investment in the manufacturing sector. We estimate reduced form investment equations augmented with variables that capture the importance of financing constraints. Along these lines one may think of changes in internal funds (cash flow) and working capital investment. We hypothesize first and foremost that investment is not systematically driven by cash flow for firms that face no financing constraints. When financing constraints are binding, however, we do expect a systematic and positive cash flow impact on investment. Thus we arrive at the workhorse in this field of study and estimate investment equations for subsamples of firms which are a priori classified as facing binding or nonbinding financing contraints. We apply this methodology to a sample of 206 large and mature Dutch firms for which relevant data are available covering the period 1983-1996. 
We employ two splitting criteria to distinguish between different subsamples of firms. The first is based on retention practice, as in Fazzari, Hubbard and Petersen (1988). This well-known scheme classifies firms into different groups of observed retention practice. It is argued that firms in the high retention regime are more likely to face financing constraints than those in the low retention regime. The second is an indicator of the liquidation value of investment and is based on industry comovement of sales (cf. Guiso and Parigi, 1999). This classification scheme takes into account that financing constraints may also be industry-specific, rather than only firm-specific. So far relatively few studies have addressed whether financing constraints are affected by particular features of the industry a firm is operating in. Relevant contributions in this respect are Schaller (1993) and Chirinko and Schaller (1995) using a sample of Canadian firms and Weigand and Audretsch (1999) with data on German firms.

Our main empirical findings are the following. First, we find that cash flow does not significantly impact on investment in the full-sample estimation of the investment equation. The same result is obtained for the subsample of a priori unconstrained firms. These results are found by very few studies. Second, in contrast to Van Ees and Garretsen (1994) we find that retention practice effectively distinguishes between financially constrained and unconstrained firms in our Dutch sample. That is, high retention firms have stronger cash flow (and also working capital and bank loan accumulation) sensitivities of investment than low retention firms. This indicates that these firms are more likely to face binding financing constraints. Third, we find that the probability of costly liquidation is related to stricter financing constraints: high comovement of sales is associated with binding financing constraints. 
The paper proceeds as follows. Section 2 develops a dynamic investment model in the absence of financing constraints. Section 3 introduces and discusses the role of financing constraints into our investment model. Section 4 depicts the estimation procedure. Section 5 presents the data used and constructs the sample splitting criteria. Empirical results are presented and discussed in section 6 . Section 7 concludes.

\section{The basic investment equation}

We start by considering the corporate investment decision in the absence of financing constraints In characterizing the investment equation we aim at keeping it empirically tractable while at the same time attempting to model investment sufficiently comprehensive. We aim to achieve this by selection of specific functional forms for dynamic investment.

We have chosen to develop an empirical specification of dynamic investment in line with Bond and Van Reenen (1999). This approach takes into account that capital stock adjustment is costly and takes time, yet refrains from explicitly modelling complex adjustment (cost) technology. In fact in this setup investment dynamics are determined by an autoregressive distributed lag (ADL) characterization of capital accumulation.

For the ADL $(1,1)$ model:

$\ln \left(k_{t}\right)=\alpha_{1} \ln \left(k_{t-1}\right)+\beta_{0} \ln \left(k_{t}^{*}\right)+\beta_{1} \ln \left(k_{t-1}^{*}\right)$ 
where $k_{t}^{(*)}$ is the actual (targeted) capital stock at time t. Under the long run proportionality constraint, $\left(\frac{\beta_{0}+\beta_{1}}{1-\alpha_{1}}\right)=1$, we can subtract $\ln \left(k_{t-1}\right)$ from both sides of (1), substitute for $\boldsymbol{\beta}_{0}$ in (1) and arrive at an investment demand function of the following form:

$\Delta \ln \left(k_{t}\right)=-\beta_{1} \Delta \ln \left(k_{t}^{*}\right)+\left(1-\alpha_{1}\right)\left(\ln \left(k_{t}^{*}\right)-\ln \left(k_{t-1}\right)\right) \cdot$

Note that $\Delta \ln \left(k_{t}^{(*)}\right)$ is defined as $\ln \left(k_{t}^{(*)}\right) \quad-\ln \left(k_{t-1}^{(*)}\right)$. In order to implement this framework as an error correction mechanism, we need to specify the optimal capital stock $k^{*}$. We do so by considering a production function in which capital $(k)$ is the only factor to produce output $(Y)$ and output is a linear function of capital imputs:

$Y_{t}=F\left(k_{t}\right)=\alpha_{K} k_{t}$,

where $\alpha_{\mathrm{K}}>0$. In addition, we assume a sufficient degree of monopolistic competition to ensure a downward sloping demand function for output:

$p_{t}=B Y_{t}^{-\frac{1}{n^{D}}}$

where $B$ is a demand shift parameter and $\eta^{D}>1$ implies a price elastic demand for output. The static optimal capital demand is obtained from the following simple maximization problem: 
$\begin{array}{ll}\max & p_{t} Y_{t}-r_{t} k_{t} \\ \text { s.t. } & p_{t}=B Y_{t}^{-\frac{1}{n^{D}}}, Y_{t}=\alpha_{k} k_{t}\end{array}$

where $r_{r}$ is the (exogenous) rental price of capital. The solution to this maximization problem is the static optimal capital stock $k_{t}^{*}$, which in the present setup may be interpreted as long run or desired capital stock:

$k_{t}^{*}=Y_{t}\left(\frac{r_{t}}{p_{t}\left(1-\frac{1}{\eta^{D}}\right)}\right)^{-1} \cdot 1$

This gives a log-linear representation for $k_{t}^{*}$, as shown in equation (7).

$\ln \left(k_{t}^{*}\right)=\ln \left(1-\frac{1}{\eta^{D}}\right)+\ln \left(Y_{t}\right)-\ln \left(\frac{r}{p}\right)$

Simple substitution of equation (7) into equation (2) gives us the dynamic investment equation

$$
\Delta \ln \left(k_{t}\right)=\left(1-\alpha_{1}\right) \ln \left(1-\frac{1}{\eta^{D}}\right)-\beta_{1} \Delta \ln \left(Y_{t}\right)-\beta_{1} \Delta \ln \left(\frac{r}{p}\right)_{t}+\left(1-\alpha_{1}\right)\left(\ln \left(Y_{t}\right)-\ln \left(k_{t-1}\right)\right)-\left(1-\alpha_{1}\right) \ln \left(\frac{r}{p}\right) .
$$

$1 \quad$ Please note that Bond and Van Reenen (1999) derive a very similar first order condition for capital from a more comprehensive specification of the production function (constant elasticity of substitution characterization of production with labour as an additional factor of production). Here too, our simplified representation of the production process does not lead to loss of generality. 
We use equation (8) as our basic investment equation. In the absence of financing constraints we expect the variables in (8) to be sufficient statistics for the determination of investment. This characterization is simple, yet explicitly allows for a role of complex adjustment processes and adjustment cost technologies through use of the ADL specification. Our investment equation is essentially neo-classical in format as it includes a measure of sales or output and a cost of capital measure. $^{2}$

\section{$3 \quad$ Financing constraints}

So far we have discussed the investment decision separate from the financing decision. This is justified under the assumption of a perfect capital market so that the irrelevance theorem holds and firms invest according to equation (8) above. However, financing becomes non-trivial in the investment decision when firms face binding financing constraints so that they take into account additional factors that were not included in equation (8), such as the availability of internal funds. We define binding financing constraints according to Fazzari, Hubbard and Petersen (1996; p. 4, footnote 1) as "conditions that raise the cost of external finance (debt or equity) above the opportunity cost of internal finance". We illustrate the impact of binding financing constraints on investment in figure 1 by considering a static investment decision. The figure shows three negatively sloped investment demand functions $\left(\mathrm{I}^{\mathrm{I}}, \mathrm{I}^{\mathrm{II}}, \mathrm{I}^{\mathrm{III}}\right)$ and one supply schedule for finance. The

\footnotetext{
2 Our investment model does not include Tobin's Q. One reason we have chosen this framework is that
} we have no information concerning the market value of equity, so that we are not able to measure Tobin's Q. 
latter schedule is initially flat and indicates that internal funds are available at the opportunity cost of internal finance which is assumed constant. External finance is more expensive. In particular, the marginal cost of finance rises with increasing use of debt and is highest (but constant) for new equity issues.

The cost of external funds may be raised above the opportunity cost of internal finance for two major reasons. First, new equity issues may carry an equity and/or lemon's premium. The lemon's premium may vary between firms depending on how well-informed investors are about the firm. In general, however, the lemon's premium on equity is assumed to be unrelated to the amount of equity outstanding (cf. Fazzari, Hubbard and Petersen, 1988). Therefore, in figure 1 the slope of the cost of funds in the regime where new equity is issued is flat. Second, debt may carry a default premium. The default risk premium on debt is not unrelated to the size of the debt burden. In fact, the very first increments to debt are nearly risk-free. Therefore, at low levels of debt, its cost hardly exceeds the opportunity cost of internal finance. When leverage increases, however, lending to the firm becomes more risky from the lender's point of view. This may be due to, for example, a rising risk of default or lack of collateral (Hubbard, 1998). The cost of debt therefore increases with the amount of debt outstanding. Therefore, in figure 1 the slope of the cost of funds in the regime where new debt is accumulated is positive.

\section{INSERT FIGURE 1 ABOUT HERE}

As figure 1 shows, this setup results in firms financing investment according to a financing hierarchy. Whenever internal funds are available, firms will use these funds first. For those cases 
where internal funds are sufficient to meet required investment (at an investment demand $\mathrm{I}_{\mathrm{I}}$ in figure 1) this suffices. In this situation we say that firms operate in financing regime I. When investment demand exceeds internal funds, but not sufficiently so to justify new equity issues (at investment demand $\mathrm{I}_{\mathrm{II}}$ in the figure), firms finance with a mix of internal funds and debt. We call this financing regime II. At investment demand as strong as $\mathrm{I}_{\mathrm{III}}$ using all internal funds and borrowing up to a debt level that equates the cost of new debt with that of new equity does not suffice to finance investment. Now the firm additionally has to raise new equity. We label this financing regime III.

Whenever the firm has investment demand relative to internal funds such that it operates in either regime II or III, it faces binding financing constraints. Binding financing constraints imply that investment would increase if the firm could replace externally generated sources of funds by internal financial resources. In a dynamic context, we can observe from figure 1 that firms in financing regime I have no incentive to increase investment when internal funds become available in future time periods, but firms in regimes II and III do have this incentive. Hence if financing constraints are relevant and the firm operates in financing regime II or III, investment is sensitive to changes in internal funds. All else equal, the sensitivity of investment to internal financial resources in regime II depends on the steepness of the debt supply curve. Firms operating in regime III also have an incentive to increase investment if internal financial resources increase. Due to the higher cost of external finance these firms have invested less than they would have in case enough internal financial resources had been available. In other words their desired capital stock $\left(\mathrm{K}^{\mathrm{III}, *}\right)$ is higher than their actual capital stock $\left(\mathrm{K}^{\mathrm{III}}\right)$. 
It should also be clear from figure 1 that observed investment may not be useful to identify the investment equation when financing constraints are relevant. Similarly, in a dynamic specification of investment with binding financing constraints, the observed availability of internal funds is no indicator for the relevance of financing constraints since firms that face especially strict financing constraints may have a precautionary demand for internal funds. ${ }^{3}$

For these reasons, we adopt the approach proposed by Fazzari, Hubbard and Petersen (1988) to indirectly measure the importance of financing constraints in investment decisions for the firms in our sample. This approach relies on a priori identification of the financing regime and the expected sensitivity of investment to changes in internal funds (cash flow) per regime. As argued above, investment of firms in financing regimes II and III is sensitive to changes in internal funds. Investment of regime I firms is not. Therefore, if we identify a firm's financing regime, we can investigate the impact of changes in internal funds on investment to grasp the relevance of financing constraints. We perform this identification along the lines of Fazzari, Hubbard and Petersen (1988) and determine whether or not firms face financing constraints on the basis of retention practice. ${ }^{4}$ Hence we regard firms that pay little or no dividends to face binding financing constraints and to operate in either regime II or III. De Haan (1997) and Van Ees, Garretsen, De

3 This is a familiar result from the real options literature, where uncertainty reduces the willingness to invest now as opposed to waiting to see which projects are really worthwhile. Financing constraints reduce the number of projects a firm can invest in and hence increase the payoff to knowing for sure which projects are going to be the real winners (see van de Laar and Letterie, 2001).

$4 \quad$ This builds on the notion that it is never optimal for a firm to issue new shares and pay dividends at the same time, when the tax rate on dividends exceeds that on capital gains. 
Haan and Sterken (1998) find that, for Dutch firms, retention practice effectively sorts out financially constrained firms.

Furthermore, along the lines of Shleifer and Vishny (1992) we argue that a firm's ability to finance investment depends on the liquidation value of the investment outlays. Shleifer and Vishny (1992) relate liquidation values to debt capacity. They show that higher liquidation costs reduce debt capacity. This implies that firms which have the lowest ex ante liquidation costs are the firms with the highest debt capacities since these firms can provide more valuable collateral to their loans. In line with Hubbard (1998) we regard these collateralized loans to be a close substitute of internal funds. In this regard, "Internal funds" in figure 1 now refers to both internal funds as well as collateralized new debt. Similarly, "New debt" now refers exclusively to uncollateralized new debt. For firms with low liquidation values of investments, therefore, the sum of internal funds and collateralized debt, all else equal, is probably lower than for firms with high liquidation values of investment. ${ }^{5}$ The former firms are thus more likely to engage in uncollateralized loans, i.e. operate in regime II or even III. Hence, we expect these firms to exhibit a relatively higher sensitivity of investment to changes in internal funds like cash flow.

In the present setup of financing constraints, we have to consider the investment decision in conjunction with the firm's financing regime. For firms in the first financing regime, we expect the investment equation to take the form of equation (8). In these circumstances investment is driven solely by neo-classical fundamentals. For firms in regimes II and III, however, equation (8) does not explain all aspects of the investment decision. For these firms, we have to augment the

5 In addition, one may want to argue that the steepness of the debt supply schedule also increases when liquidation values fall. This would only reinforce our hypothesis. 
investment equation with a measure of changes in internal funds (cash flow). The remainder of this section introduces two further variables that capture or are related to financing constraints.

First, we implement the idea developed by Fazzari and Petersen (1993) that the impact of working capital on investment also signals the relevance of financing constraints. ${ }^{6}$ Suppose, for instance, that the positive cash flow sensitivity of investment is artificial and that it is simply the result of unobserved changes in profitability of investment reflected in higher cash flow. If this hypothesis is true, then all types of investment should go up simultaneously, including investment in working capital. This translates into a positive expected coefficient on net working capital in the investment equation. If, however, we want to maintain the assumption that cash flow measures the size of the internal financial market, then the role of working capital is more that of a use of (internal) funds. In that case investment in working capital competes with investment in fixed assets for funds. Then we expect a negative coefficient on working capital in the investment equation. A negative coefficient on working capital in the investment equation therefore signals the relevance of financing constraints. It also justifies the interpretation of cash flow sensitivity of investment as stemming from financing constraints. ${ }^{7}$ Investment in working capital is therefore added to the investment equation to provide additional insight into the relevance of financing constraints.

6 Working capital is the sum of cash, short term claims and inventories less short term debt and hence refers to a potential (temporary) source of internal funds the firm may wish to use for the financing of new investment.

7 Furthermore, Fazzari and Petersen (1993) suggest that if working capital is excluded from the empirical model cash flow sensitivities may be underestimated. 
Second, we follow Weigand and Audretsch (1999) and add long term debt accumulation to the investment equation as a proxy for the use of monitored capital. This line of reasoning stems from the empirical focus of these authors on the German corporate sector, in which banks play an important role in financing. The importance of German banks is reflected by the large share of long term bank loans in total corporate German debt. Hence long term debt may proxy for the monitoring intensity of banks. When firms are able to raise additional monitoring capital, we expect the financing constraints to soften. This allows for investment increases. Therefore, we expect long term debt accumulation to stimulate investment. In addition, Weigand and Audretsch (1999) ague that the impact of a higher monitoring intensity is likely larger for constrained German firms. In a study of financing constraints in the Dutch corporate sector, Van Ees and Garretsen (1994) as well as De Haan (1997) find that for the Dutch business sector bank relations also play an important role in the mitigation of financing constraints. Since the role of banks in Dutch and German corporate financing is comparable, we also include long term debt accumulation in our empirical investment equation. ${ }^{8}$

\section{$4 \quad$ Estimation}

We specify the empirical investment equation in line with the theoretical investment equation represented by equation (8). Unfortunately, data limitations do not allow us to include either the

\footnotetext{
8 In addition, De Haan and Hinloopen (1999) p. 3, document that "the public capital market for corporations is relatively thin, with a few large firms issuing stocks and bonds and the bulk of the firms using only private loans (mostly bank loans) when external finance is required".
} 
demand elasticity for firms' output or the real rental price of capital. We assume that the impact of these variables will be captured by time and firm fixed effects. ${ }^{9}$ Please note that dropping the rental price of capital transforms our neo-classical specification of capital demand into a de facto accelerator model. ${ }^{10}$ In addition, we add cash flow, working capital investment and long term debt accumulation as additional variables to capture the impact of financing constraints. We estimate the following model of investment:

$$
\frac{I_{i t}}{A_{i t-1}}=\beta_{1} \Delta \ln S_{i t}+\beta_{2} \ln \frac{S_{i t}}{A_{i t-1}}+\beta_{3} \frac{C F_{i t}}{A_{i t-1}}+\beta_{4} \frac{\Delta W C_{i t}}{A_{i t-1}}+\beta_{5} \frac{\Delta L T D_{i t}}{A_{i t-1}}+\mu_{i t} .
$$

In this equation the variables are indexed by firm (i) and year (t), I captures investment in fixed assets, $A$ measures total assets, $S$ is sales, $C F$ stands for cash flow, $W C$ is working capital and $L T D$ measures long term debt. The exact definition of the variables follows in the next section. Variables for which the natural logarithm is included in the regression model are preceded by $\ln$ and $\Delta$ is the first difference operator.

The theoretical specification of the investment function (equation 8) results in a negative expected sign for $\beta_{1}$ and a positive $\beta_{2}$. For unconstrained firms, the two sales variables to which

9 Regarding the impact of omission of the real rental price of capital Chirinko (1993) argues that price variables are unimportant relative to quantity variables in investment equations and more importantly, their omission does not lead to considerable changes in the other parameter estimates.

10 See for example Bond and Van Reenen (1999), p. 33, or Fazzari, Hubbard and Petersen (1988), p. 176. 
these parameters pertain are also expected to be sufficient statistic for the determination of investment. The coefficient on cash flow, $\beta_{3}$, is expected to be positive only when financing constraints matter, while this interpretation requires a negative parameter estimate for $\beta_{4}$. Under the maintained hypothesis that long term debt proxies monitoring capital and in this manner stimulates investment, the estimated coefficient on long term debt accumulation, $\beta_{5}$, is positive and likely stronger positive when financing constraints are more relevant.

We estimate equation (9) including firm specific effects to allow for unobserved heterogeneity across firms and periods of time and possible bias due to the non-random nature of the sample. This implies that

$$
\mu_{i t}=\alpha_{i}+\lambda_{t}+v_{i t}
$$

where $\alpha_{i}$ captures the fixed firm-specific (time-invariant) effects, $\lambda_{t}$ captures the fixed timespecific (firm-invariant) effects and $v_{i t}$ is a white noise error term.

We also recognize the potential endogeneity of investment in net working capital and long term debt accumulation. We adopt a two-stage least squares approach (i.e. within 2SLS, see also Baltagi, 1981) and instrument these variables with their lagged levels. The treatment of working capital investment as potentially endogenous is straightforward. Investment in working capital and fixed capital are both uses of funds. Therefore, investment in working capital is likely to be simultaneously decided with investment in fixed assets. The treatment of long term debt 
accumulation as potentially endogenous reflects uncertainty regarding the direction of causation. Increases in long term debt may facilitate investment by reducing financing constraints. In this scenario, long term debt is an exogenous variable. However, it is also conceivable that long term debt is increased when profitable investment opportunities emerge. Investment is then the trigger for long term debt accumulation and the direction of causation is reversed (cf. Weigand and Audretsch, 1999).

\section{The data and the definition of splitting criteria}

As argued before, the extent to which financial variables affect the investment decisions of firms depends on the particular financing regime it operates in. Hence, we have to consider the investment function for each financing regime individually. This leads to the well-accepted splitsample analysis of investment equations in the field of research that addresses the importance of financing constraints. ${ }^{11}$ The present section introduces the data used in the empirical analysis and defines in detail the splitting criteria. We conclude with a statistical summary of the sample in total and by sample split.

\section{Sample selection}

In the empirical analysis we make use of Statistics Netherlands' SFGO sample, which collects balance-sheet and income statement data on a nonrandom sample of Dutch firms. The sample is

\footnotetext{
11 See for example Fazzari, Hubbard and Petersen (1988), Hoshi, Kashyap and Scharfstein (1991), Schaller (1993), Van Ees and Garretsen (1994), Vogt (1994) and Gilchrist and Himmelberg (1995). 
devised to collect information on the entire population of Dutch firms for which the total balance sheet length exceeds HFL 20 million in current prices. In practice, the annual response rate is roughly eighty percent, so that the SFGO sample includes nearly 30,000 firm-years of observation. The sample covers the period 1977-1997. We extract from this sample a balanced panel of Dutch manufacturing firms, thus following the majority of papers in this field of research. Manufacturing firms are identified according to SBI74 classification. At the two-digit SBI74 level, sectors 20 up to and including 39 are included in the manufacturing sector. ${ }^{12}$ Due to attrition, we find it optimal to select the years ranging from 1983 to 1996 so that we have information on all the relevant variables for a total of 206 firms. We combine this information with sectoral data collected by Statistics Netherlands, which contains industry sales and price indices at the two-digit level. ${ }^{13}$

\section{Splitting criteria}

We are interested in the role of financing constraints in different regimes of financing. To that end we want to find out whether sensitivity of investment to changes in internal funds resembles the shape of the supply of funds curve in figure 1. To construct our sample split criteria, we use information for the period 1983-1991 to assess the probability that a firm operates in regime I or

\footnotetext{
12 More specifically, the sectors are Food and goodies (20/21), Textile (22), Clothing (23), Leather, shoes and leatherware (24), Wood and furniture (25), Paper and related (26), Graphic industry and publishers (27), Petroleum (28), Chemical (29), Synthetic strings and fibres (30), Rubber and synthetics processing (31), Building materials, pottery, glass (32), Basic metal (33), Metal products (34), Machines (35), Electronics (36), Transports (37), (Optical) instruments (38), Other (39).

13 The sectoral data can be found in "Samenvattend overzicht van de industrie, K-160". Price information is confidential.
} 
in one of the regimes II and III. For firms in financing regime I, financing constraints are not expected to have a meaningful impact on the estimated investment equation. In regimes II and III we do expect financial variables to significantly and positively impact on investment. The remaining five years from 1992 to 1996 are then used to estimate the importance of financing constraints in investment equations. We have chosen to split the sample this way to avoid that the financing regime may be endogenously determined itself.

Our first splitting criterion is based on retention practice, as in Fazzari, Hubbard and Petersen (1988). Our classification scheme identifies only two retention classes (low and high) as opposed to Fazzari, Hubbard and Petersen who also identify a medium retention class. ${ }^{14} \mathrm{We}$ allocate firms to the high retention class when, in the period 1983-1991, the firm had a dividend payout rate of less than ten percent in six years or more. The dividend payout rate is defined as dividends over profits.

Not all companies in the sample have issued shares. When a firm has not yet issued any shares it does not pay dividends. Our classification scheme automatically judges them to belong to the high retention class. In fact, however, these are probably the firms that have always had investment demand such as $\mathrm{I}_{\mathrm{I}}$ or $\mathrm{I}_{\mathrm{I}}$. Therefore, we possibly classify these firms incorrectly to the high retention class. We check for all the firms in the high retention class whether they had shares outstanding during the entire 1983-1991 period. We find for five firms that they had no shares

14 The data we analyse do not allow us to construct a medium retention class since less than 10 firms would satisfy the usual criterion, i.e. making dividend payments of more than $10 \%$ but not exceeding $20 \%$ for at least two out of every three sample years. Considering a wider medium class - dividend payments ranging from $10 \%$ to $25 \%$ and even $30 \%$ - did not solve this problem sufficiently. 
outstanding, all other firms issued their first shares prior to 1983 . We marked the retention class as missing value for the five former firms. Of the remaining 201 classifications, 82 are in the high retention class and 119 are in the low retention class.

Our second splitting criterion is based on the liquidation value of investment. ${ }^{15} \mathrm{We}$ construct an indicator of asset liquidity based on industry comovement of sales. The idea builds on Shleifer and Vishny (1992) to the extent that it attempts to capture the liquidation value of the firm. The cost of liquidation depends on whom assets can be sold to when liquidation is required. Firms in the same line of business are the next best users of the assets. Hence, the liquidation cost is lowest when it is possible to sell the assets to a firm in the same business. If firm and industry sales are highly correlated, which by definition implies a high degree of comovement, then the firm and industry face declining demand at the same time. In such a case the liquidation value is expected to be low. Since the other firms are likely to face difficulties in generating financial resources themselves to purchase the second-hand capital assets of their competitors or find no interest in expanding their business at that time, the probability that the firm sells its assets to a firm in the same line of business decreases with the degree of comovement of the firm and industry sales.

We use two measures of comovement for each firm. The first is the correlation of the logarithms of the levels of firm and industry sales during the period 1983-1991. The second is the correlation of the first differences in the logarithms of firm and industry sales during the period 1984-1991. Since our results below do not depend on the choice of these two ways of measuring comovement we only report our results based on the second measure. The sector information regarding (real) sales was obtained from Statistics Netherlands. This data contains information on 
industry sales and price indices at the two-digit level sector level according to the SBI74 classification scheme. We could not compute this measure of comovement for firms in sectors 27 and 38 as price indices where not available for these sectors and hence sales could not be deflated. Fourteen firms were in these two sectors. In addition, sales data were not available for sectors 20 and 21 separately, but only for both sectors jointly. Therefore, we deflated these combined sectorsales with the average price index of the two sectors and treated these two sectors as a single one. ${ }^{16}$ For sectors 29 and 30 sales were likewise not reported for the sectors separately but only for the two sectors jointly. Moreover, the price index for sector 30 was unavailable as well. Since approximately ten percent of our sample consisted of firms in sector 29 (but none in sector 30), we were reluctant to eliminate these observations. Instead, we deflated the combined sales of sectors 29 and 30 with the price index for sector $29 .{ }^{17}$

Comovement is a continuous variable rather than the discrete classification of retention practices. For each individual firm, however, it is a constant. Comovement varies from -0.90 to 0.92. The $25^{\text {th }}$ percentile, median and $75^{\text {th }}$ percentile are $-0.21,0.11$ and 0.36 , respectively. The mean value is 0.07 . We consider comovement to be low when the correlation between firm and industry sales is lower than 0.11 (the median). Comovement is medium if it in between 0.11 and 0.36 (the third quartile), and it is high when the correlation exceeds 0.36 . The classification is admittedly ad hoc. However, the results presented in the next section reveal that meaningful

16 The correlation of the price indices of the individual sectors was nearly 90 percent in levels and 70 percent in first differences. Therefore, the loss in accuracy using the aggregate deflator is probably not large.

17 Our estimation results presented in the next section are not affected by excluding sectors 29 and 30. To save space we do not report these. 
differences exist between these three groups (in terms of both descriptive statistics as well as regression results), while further subdivision of the low comovement group does not generate new insights regarding investment behaviour of these firms.

\section{Descriptive statistics by sample split and in total}

Table 1 provides descriptive statistics for the firms in our sample. Mean, standard error, median and number of firms are reported for the full sample and by sample split. We describe the sample and sub-samples by investment, sales, long term debt, working capital and cash flow characteristics. Investment is defined as changes in tangible fixed assets due to purchase or production. Working capital measures the sum of cash, inventories and short term claims less short term debt. Cash flow is defined as earnings after interest and taxes, but before depreciation and dividends.

\section{INSERT TABLE 1 ABOUT HERE}

Columns 2 and 3 show the differences between low and high retention firms in terms of financial characteristics. High retention firms invest slightly less, have a lower level of sales and, on average, their sales grew at a slower rate. ${ }^{18}$ High retention firms also have slightly lower levels of

\footnotetext{
This is different from the findings of Fazzari, Hubbard and Petersen (1988). For their sample of Value Line firms, they find that high retention firms have the highest investment rates and the fastest sales growth rates. Their sample consisted of young firms, however, whereas our sample is constructed from a data base of large and mature firms.
} 
working capital, although the annual investment in working capital is comparable to that of low retention firms. The most important difference between the two classes of firms is in terms of debt rates and debt accumulation. High retention firms have a considerably larger debt burden, but at the same time are hardly accumulating any new debt. Hence the selection on the basis of retention is likely to identify correctly the firms operating in regimes II and especially III. Finally, high retention firms have larger cash flow ratios than low retention firms.

Columns 4, 5, and 6 present financial characteristics for the sub-samples of firms with low, medium, or high comovement. From these columns it is clear that the financial characteristics of firms also differ when we rank them by comovement. The pattern is not monotonic in most cases, however. Investment is roughly equal for low and medium comovement firms, but considerably lower for high comovement firms. Our explanation for this observation is that firms in the high comovement industries find it harder to attract external financial resources to fund such investment because of low liquidation values as we explained before. Sales level, working capital ratio and investment in working capital are similar for high and low comovement firms but lower for medium comovement firms. Medium comovement firms exhibit the fastest sales growth rates. Cash flow is almost identical on average across the three sub-samples. Again, the most important observations relate to debt rates and accumulation. The relative debt level for low and medium comovement firms is roughly equal. For high comovement firms, however, it is lower. In addition, average debt accumulation falls monotonically when comovement increases. This is in line with our expectations again, since a higher degree of comovement makes it more difficult to attract external financial resources due to a lack of potential collateral that firms can offer to external providers of finance. 


\section{Results}

Full sample results: 1992-1996

Table 2 presents regression results of the determinants of investment for the full sample for the period 1992-1996. ${ }^{19}$ We focus first on the second column where results are presented using all 206 firms in the sample. The coefficients on the sales terms have the expected signs and are highly significant. Annual sales growth enters with a negative sign and the sales to assets ratio contributes positively to investment. Surprisingly, there is no statistically discernible impact of cash flow on investment. The point estimate is positive, but small and barely exceeds the standard error. Few other studies find that cash flow has no impact on investment and the studies that do usually derive those results from the subsample of a priori unconstrained firms. ${ }^{20}$ While this indicates absence of binding financing constraints for the full sample, the estimated signs and significance of working capital investment and long term debt accumulation suggest otherwise. Working capital has a negative and significant impact on investment, indicating that working capital and fixed asset

19

The strength of our instruments was tested for in all regression equations reported in tables 2 and 3. The joint significance of the instruments in the first stages exceeded the critical F-value advised by Staiger and Stock (1997) by a fair margin.

20 Among the studies that employ split sample analysis of reduced form investment equations, Oliner and Rudebusch (1992), Gilchrist and Himmelberg (1995) and Hsiao and Tahmiscioglu (1997) find insignificant cash flow impact on investment. In all three cases these findings refer to the sub sample of a priori unconstrained firms. Whited (1992) presents similar findings in a split sample analysis of Euler equations. 
investment compete for a limited pool of funds. ${ }^{21}$ Endogenous long term debt accumulation stimulates investment, suggesting that debt acquisition ameliorates financing constraints. ${ }^{22}$

\section{INSERT TABLE 2 ABOUT HERE}

As explained before, the construction of sample splitting criteria results in the loss of observations. In particular, we have no information regarding retention class for five firms and no indication of comovement for another fourteen firms. Splitting the sample may generate different cash flow sensitivities due to sample selection rather than binding financing constraints. On the other hand, deleting these observations from further analysis would result in loss of nearly ten percent of our sample. As a middle way, we run the investment regression on three sub-samples of data as well (columns 3, 4 and 5), covering the instances in which we have no information regarding retention class and/or comovement. The stability of parameter estimates across these three alternative samples suggests that the eliminated observations do not contain any other information than that reflected in the original estimates. In other words, our results here and those presented in the next section are not likely to be driven by such sample selection issues.

21

The magnitude of the parameter estimate is much lower than presented in Fazzari and Petersen

(1993). In fact, our estimate does not exceed -0.10 while theirs (in a q-model) it is -0.18 for a priori unconstrained firms and -0.43 for a priori constrained firms. For regressions including sales, they find a working capital impact of -0.22 , still twice as large as our estimate. Our findings are more in line with those presented by Weigand and Audretsch (1999), who find a working capital impact on investment of -0.12 .

22 The impact of long term debt on investment corresponds in magnitude with findings presented by Fazzari and Petersen (1993) as well as Weigand and Audretsch (1999). 


\section{Split sample analysis}

Table 3 presents regression results for investment equations of firms where the sample is univariately split according to retention practice and comovement classes. Columns 2 and 3 contrast low and high retention class firms. As explained before, high retention firms are likely those firms that have a high probability of operating in financing regimes II or III. They are therefore a priori (more) constrained than low retention firms. We find that low and high retention class firms do not differ in responsiveness to the sales-to-assets ratio or sales growth. The differences between the two classes of firms lie entirely with those variables we associate with the presence of financing constraints. In particular, cash flow, working capital investment and debt accumulation are insignificant at the five percent level for low retention firms. The coefficient on cash flow even takes on a negative value. For high retention firms, on the other hand, these three variables have signs that suggest that financing constraints matter and additionally, all are significant at the five percent level or better. These results are in line with many studies reporting on the relevance of financing constraints using retention practice as a sorting device (Fazzari, Hubbard and Petersen (1988), Fazzari and Petersen (1993), Vogt (1994), Gilchrist and Himmelberg (1995)). At the same time, however, our finding contrast sharply to the one study that uses a comparable set of data. Van Ees and Garretsen (1994) report that financing constraints matter in Dutch corporate investment, but retention practice does not effectively discriminate between constrained and unconstrained firms. Unfortunately, the study does not report the estimation results of this exercise so that we cannot compare the magnitude of our estimates (which are quit low in absolute terms by international standards, we return to this issue at the end of this section) with theirs. ${ }^{23}$ 


\section{INSERT TABLE 3 ABOUT HERE}

In columns 4, 5 and 6 regressions results are presented where the sample is split according to sales comovement into low, medium and high comovement. Comparing low and high comovement firms, we find that sales matter little for the latter class of firms. Regarding the variables signalling the presence of financing constraints, working capital investment is negative and statistically discernible for the low comovement firms, but both cash flow and debt accumulation are indiscernible from zero. For the high comovement firms, however, working capital investment is more negative and cash flow and debt accumulation are positive and significantly so at conventional levels. It should be noted, however, that the changes in parameter estimates are not monotonic across comovement classes for most variables. The parameter estimates for cash flow and debt accumulation are the only two that increase monotonically when comovement increases. The effect of working capital investment is larger for high comovement firms than for low comovement firms, yet the difference is not statistically significant and the coefficient peaks low for the medium comovement firms. ${ }^{24}$

Exchange in the years 1984-1990. Estimation results are derived for the period 1985-1990. The methodological differences between their research and ours are the following. First, we select manufacturing firms, which is only a subsample of all non-financial firms. Second, we derive results from the years 1992-1996, not 1985-1990. Third and most important, we construct our sample splitting criteria using the years 1983-1991 and subsequently analyse financing constraints out-of-sample, whereas Van Ees and Garretsen (1994) construct these splits from the same data they analyse investment equations from.

24 We have also estimated equation (9) using bivariate splits by subdividing the low and high retention classes into low, medium and high comovement. To save space we do not report these results. Furthermore, due to 
Overall, we find that financing constraints matter in Dutch corporate investment in manufacturing firms and can be identified using both retention and firm-industry sales comovement discrimination. At the same time, however, our estimation results regarding cash flow sensitivities show relatively small absolute cash flow impact on investment. In comparison, Fazzari, Hubbard and Petersen (1988) find a cash flow impact on investment ranging from well over 0.20 for unconstrained firms to as high as 0.50 for constrained firms. We want to discuss two factors that we think contribute to these differences. First, we estimate a sales accelerator model and this generally produces lower cash flow estimates than a q-approach. In fact, Fazzari, Hubbard and Petersen (1988) consider a sales accelerator model as an alternative specification of investment and see their cash flow sensitivities of investment drop by as much as $50 \% .^{25}$ Second, the data we use may be biased against finding relevant financing constraints. We restrict our international comparison here to the study by Fazzari, Hubbard and Petersen (1988) who base their findings on a sample of Value Line firms. The structure of these data is such that it includes young firms that

the relatively small samples that resulted from this subdivision, many of the parameters were found to be statistically insignificant. One result we found was that for the low retention class firms, the cash flow sensitivity of investment increases across comovement classes.

25 A possible explanation is the following. In a q-approach as well as a sales accelerator model, we would expect financial variables to be irrelevant in the investment decision of unconstrained firms. The only factor that should determine investment is the expected profitability of the investment. The technical complications in measuring $\mathrm{q}$ and the potential for mismeasurement might lead to a relatively large informational content of cash flow regarding expected investment profitability. In a sales accelerator model, the potential for mismeasurement is much lower, so that cash flow has a much lower probability to convey additional information concerning profitability that is not already embodied in sales information. 
are not at all well-known to the public for the main part of the sample period. In other words, firms in their sample are likely to be exactly the firms that face binding financing constraints due to information problems. In contrast, our sample consists of the largest Dutch firms that belonged to the group of largest Dutch firms from the start of the sample period. These are firms that may face a lower degree of financing constraints simply because they may have overcome information problems to a certain extent and are well-known by the public.

\section{Conclusion}

Financing constraints matter in the investment decisions of 206 of the largest and probably most mature Dutch manufacturing firms. This is the conclusion from our split-sample analysis of reduced form investment equations. The investment function of a priori constrained firms is materially different from the investment function of an a priori unconstrained firm. More specifically, in the latter case investment can be meaningfully characterized using a simple sales accelerator approach. Working capital investment and long term debt accumulation weakly impact on investment in this situation. For a priori constrained firms, however, sales accelerator arguments reflect only part of the investment decision. For these firms, cash flow and long term

debt accumulation are systematically and positively related to investment while working capital investment competes with investment in fixed assets for a limited pool of finance. This corroborates with an explanation based on capital market imperfections such that firms abide by a financing hierarchy. 
We also show that financing constraints are associated with firm-specific factors as well as aspects of the economic environment the firm operates in. In particular, our results indicate that financing constraints are binding for firms that follow a high retention practice. This finding suggests that firms have investment opportunities that cannot be profitably deployed using external funds, but are profitable when internal funds are available. Additionally, investments with low liquidation value appear more difficult to finance with external funds than investments with a high liquidation value. This finding suggests that there may be investments that cannot be financed with external funds due to lack of collateral (the result of low liquidation value) but can be profitably financed when internal funds are available.

Interestingly, the estimation results clearly demonstrate that for the a priori unconstrained firms cash flow, working capital investment and long term debt accumulation have a limited impact at best. We propose the sales accelerator specification of the investment function as a partial explanation, but consider the particular features of our sample (consisting of large, mature and well-known firms) to contribute mostly to this finding. The fact that we find evidence of financing constraints in this particular sample suggests at least that our findings provide a lower bound for the relevance of financing constraints in the Dutch business sector at large. Young, small firms that are not yet well-known to the public are likely to face stricter financing constraints as their risk premium on debt and lemon's premium on equity additionally reflects lack of information regarding structural behaviour and performance.

Finally, we think it is appropriate to mention the link between sales comovement and investment irreversibilities. If sales comovement proxies the liquidation value of investment, then we can also interpret it as a proxy of the irreversibility of investment. Higher sales comovement 
indicates a lower degree of reversibility in this respect. If this line of reasoning is correct, however, we have to take into account that a higher sales comovement may not only affect investment through the reduced ability to acquire external funds. In addition, then, higher sales comovement, all else equal, may also reduce the incentive to invest. This is a well-known conclusion from the real options literature (see Dixit and Pindyck, 1994). We did not consider this secondary impact of sales comovement on financing constraints in this paper, but leave it as a direction for further research. 


\section{References}

- $\quad$ Baltagi, B. H. "Simultaneous Equations with Error Components." Journal of Econometrics $17(1981), 189-200$.

- $\quad$ Bond, S., and J. Van Reenen. Microeconometric Models of Investment and Employment, manuscript, June 15, 1999.

- Chirinko, R. S. "Business Fixed Investment Spending: Modelling Strategies, Empirical Results and Policy Implications.” Journal of Economic Literature 31 (1993), 1875-1911.

- Chirinko, R. S., and H. Schaller. "Why Does Liquidity Matter in Investment Equations." Journal of Money, Credit, and Banking 27 (1995), 527-548.

- Dixit, A.K., and R.S. Pindyck. Investment under Uncertainty, Princeton University Press, 1994.

- $\quad$ Ees, H. van, and H. Garretsen, "Liquidity and Business Investment: Evidence from Dutch Panel Data.” Journal of Macroeconomics 16 (1994), 613-627.

- $\quad$ Ees, H. van, Garretsen, H., De Haan, L. de, and E. Sterken. "Investment and Debt Constraints: Evidence from Dutch Panel Data.” In: Market Behaviour and Macroeconomic Modelling, edited by S. Brakman, H. van Ees, and S. K. Kuipers, pp. 159-169, Macmillan Press, 1998.

- $\quad$ Fazzari, S. M., Hubbard, R. G., and B. C. Petersen. "Financing Constraints and Corporate Investment." Brookings Papers on Economic Activity 1 (1988), 141-195.

- $\quad$ Fazzari, S. M., Hubbard, R. G., and B. C. Petersen. "Financing Constraints and Corporate Investment: Response to Kaplan and Zingales.” Working Paper 5462, National Bureau of Economic Research, 1996. 
- $\quad$ Fazzari, S. M., and B. C. Petersen. "Working Capital and Fixed Investment: New Evidence on Finance Constraints.” RAND Journal of Economics 24 (1993), 328-342.

- $\quad$ Gilchrist, S., and C. P. Himmelberg. "Evidence on the Role of Cash Flow in Reduced-Form Investment Equations.” Journal of Monetary Economics 36 (1995), 541-572.

- $\quad$ Guiso, L., and G. Parigi. "Investment and Demand Uncertainty." Quarterly Journal of Economics 114 (1999), 185-227.

- Haan, L. de. Financial Behaviour of the Dutch Corporate Sector, Thela Thesis, Amsterdam, 1997.

- $\quad$ Haan, L. de, and J. Hinloopen. "Debt or Equity? An Empirical Study of Securities Issues by Dutch Companies.” DNB Staff Report 41, De Nederlandsche Bank, 1999.

- $\quad$ Hoshi, T., Kashyap, A. K., and D. S. Scharfstein. "Corporate Structure, Liquidity, and Investment: Evidence from Japanese Panel Data." Quarterly Journal of Economics 106 (1991), 33-60.

- Hsiao, C., and A. K. Tahmiscioglu. "A Panel Analysis of Liquidity Constraints and Firm Investments.” Journal of the American Statistical Association 92 (1997), 455-465.

- $\quad$ Hubbard, R. G. “Capital-Market Imperfections and Investment.” Journal of Economic Literature 36 (1998), 198-225.

- $\quad$ Laar, M. van de, and W.A. Letterie. "The Option Value of Waiting to See which Project is Worthwhile.” Mimeo, Maastricht University, 2001

- $\quad$ Oliner, S. D., and G. D. Rudebusch. "Sources of the Financing Hierarchy for Business Investment.” Review of Economics and Statistics 74 (1992), 643-654.

- $\quad$ Schaller, H. "Asymmetric Information, Liquidity Constraints, and the Canadian Investment." Canadian Journal of Economics 26 (1993), 552-574. 
- $\quad$ Shleifer, A., and R. Vishny. "Liquidation Values and Debt Capacity: A Market Equilibrium Approach.” Journal of Finance 47 (1992), 1343-1366.

- $\quad$ Staiger, D., and J. H. Stock. "Instrumental Variables Regression with Weak Instruments." Econometrica 65 (1997), 557-586.

- Vogt, S. C. "The Role of Internal Financial Sources in Firm Financing and Investment Decisions." Review of Financial Economics 4 (1994), 1-24.

- Weigand, J., and D. B. Audretsch. "Does Science Make a Difference? Investment, Finance and Corporate Governance in German Industries.” Working Paper 2056, Centre for Economic Policy Research (CEPR), 1999.

- Whited, T. M. “Debt, Liquidity Constraints, and Corporate Investment: Evidence from Panel Data." Journal of Finance 47 (1992), 1425-1470. 


\section{Table 1}

Summary statistics: sample of manufacturing firms, 1983-1991

\begin{tabular}{|c|c|c|c|c|c|c|}
\hline & \multirow{2}{*}{$\begin{array}{c}\text { All } \\
\text { Firms }\end{array}$} & \multicolumn{2}{|c|}{ Retention class $^{\mathrm{a}}$} & \multicolumn{3}{|c|}{ Comovement $^{\mathrm{b}}$} \\
\hline & & Low & High & Low & Medium & High \\
\hline \multirow[t]{3}{*}{ Investment to assets } & 0.082 & 0.084 & 0.079 & 0.085 & 0.086 & 0.071 \\
\hline & $(0.002)$ & $(0.002)$ & $(0.003)$ & $(0.003)$ & $(0.004)$ & $(0.003)$ \\
\hline & {$[0.064]$} & {$[0.066]$} & {$[0.058]$} & {$[0.068]$} & {$[0.057]$} & {$[0.054]$} \\
\hline \multirow[t]{3}{*}{$\operatorname{lnSales}$} & 12.348 & 12.489 & 12.067 & 12.414 & 12.045 & 12.570 \\
\hline & $(0.029)$ & $(0.037)$ & $(0.046)$ & $(0.039)$ & $(0.060)$ & $(0.066)$ \\
\hline & [12.153] & [12.316] & [11.873] & [12.267] & [11.804] & [12.245] \\
\hline \multirow[t]{3}{*}{$\Delta \ln$ Sales $^{\mathrm{c}}$} & 0.049 & 0.052 & 0.046 & 0.049 & 0.060 & 0.037 \\
\hline & $(0.005)$ & $(0.006)$ & $(0.010)$ & $(0.008)$ & $(0.010)$ & $(0.011)$ \\
\hline & [0.049] & {$[0.051]$} & [0.049] & {$[0.050]$} & {$[0.048]$} & [0.046] \\
\hline \multirow[t]{3}{*}{$\ln$ Sales to assets } & 0.310 & 0.308 & 0.294 & 0.359 & 0.156 & 0.409 \\
\hline & $(0.013)$ & $(0.014)$ & $(0.023)$ & $(0.018)$ & $(0.027)$ & $(0.029)$ \\
\hline & {$[0.365]$} & {$[0.345]$} & [0.398] & [0.390] & {$[0.268]$} & [0.475] \\
\hline \multirow[t]{3}{*}{ Working capital to assets } & 0.174 & 0.178 & 0.169 & 0.185 & 0.165 & 0.186 \\
\hline & $(0.004)$ & $(0.005)$ & $(0.008)$ & $(0.006)$ & $(0.010)$ & $(0.008)$ \\
\hline & {$[0.160]$} & {$[0.167]$} & [0.148] & [0.182] & [0.133] & {$[0.167]$} \\
\hline \multirow[t]{3}{*}{$\Delta$ Working capital to assets ${ }^{\mathrm{c}}$} & 0.011 & 0.011 & 0.012 & 0.011 & 0.007 & 0.014 \\
\hline & $(0.002)$ & $(0.003)$ & $(0.004)$ & $(0.003)$ & $(0.005)$ & $(0.005)$ \\
\hline & {$[0.012]$} & {$[0.014]$} & {$[0.012]$} & {$[0.013]$} & [0.009] & {$[0.013]$} \\
\hline \multirow[t]{3}{*}{ Long term debt to assets } & 0.125 & 0.093 & 0.170 & 0.127 & 0.132 & 0.116 \\
\hline & $(0.003)$ & $(0.003)$ & $(0.006)$ & $(0.005)$ & $(0.007)$ & $(0.006)$ \\
\hline & {$[0.087]$} & {$[0.060]$} & {$[0.130]$} & [0.083] & [0.086] & {$[0.083]$} \\
\hline \multirow[t]{3}{*}{$\Delta$ Long term debt to assets ${ }^{\mathrm{c}}$} & 0.006 & 0.010 & 0.002 & 0.010 & 0.007 & 0.001 \\
\hline & $(0.003)$ & $(0.004)$ & $(0.004)$ & $(0.005)$ & $(0.004)$ & $(0.003)$ \\
\hline & {$[0.000]$} & {$[0.000]$} & {$[0.000]$} & {$[-0.000]$} & {$[0.000]$} & {$[0.000]$} \\
\hline \multirow[t]{3}{*}{ Cash flow to assets } & 0.061 & 0.053 & 0.071 & 0.058 & 0.061 & 0.058 \\
\hline & $(0.003)$ & $(0.004)$ & $(0.005)$ & $(0.004)$ & $(0.007)$ & $(0.006)$ \\
\hline & {$[0.078]$} & {$[0.073]$} & [0.092] & {$[0.080]$} & {$[0.073]$} & {$[0.068]$} \\
\hline $\mathrm{N}$ & 206 & 119 & 82 & 96 & 48 & 48 \\
\hline
\end{tabular}


Notes: Variable means are reported, standard error is in parenthesis, median in square brackets.

a Based on dividend payout. A firm is in the high retention class when the dividend payout rate does not exceed 10 percent for six years or more. A firm is in the low retention class otherwise.

b Comovement is low when the correlation between firm and industry sales is 0.106 or lower (the median). Comovement is medium when this correlation is in between 0.106 and 0.363 (which captures the third quartile) and it is high when the correlation exceeds 0.363 .

c Annual change in relevant variable. 


\section{Table 2}

The determinants of investment: full sample, 1992-1996

\begin{tabular}{|c|c|c|c|c|}
\hline Independent variables ${ }^{a}$ & All observations & $\begin{array}{l}\text { Excluding } \\
\text { missing } \\
\text { comovement }\end{array}$ & $\begin{array}{l}\text { Excluding } \\
\text { missing } \\
\text { retention class }\end{array}$ & $\begin{array}{l}\text { Excluding } \\
\text { missing } \\
\text { retention class } \\
\text { and/or missing } \\
\text { comovement }\end{array}$ \\
\hline \multirow[t]{2}{*}{$\Delta \ln S a l e s$} & -0.029 & -0.031 & -0.028 & -0.030 \\
\hline & $(0.010)$ & $(0.010)$ & $(0.010)$ & $(0.010)$ \\
\hline \multirow[t]{2}{*}{ lnSales to assets } & 0.059 & 0.059 & 0.059 & 0.058 \\
\hline & $(0.010)$ & $(0.010)$ & $(0.010)$ & $(0.010)$ \\
\hline \multirow{2}{*}{ Cash flow to assets } & 0.018 & 0.016 & 0.016 & 0.014 \\
\hline & $(0.015)$ & $(0.016)$ & $(0.015)$ & $(0.016)$ \\
\hline \multirow{2}{*}{$\Delta$ Working capital to assets $^{\mathrm{b}}$} & -0.099 & -0.097 & -0.091 & -0.089 \\
\hline & $(0.032)$ & $(0.034)$ & $(0.032)$ & $(0.034)$ \\
\hline \multirow[t]{2}{*}{$\Delta$ Long term debt to assets ${ }^{\mathrm{b}}$} & 0.170 & 0.169 & 0.165 & 0.164 \\
\hline & $(0.045)$ & $(0.049)$ & $(0.045)$ & $(0.049)$ \\
\hline $\mathrm{N}$ & 206 & 192 & 201 & 187 \\
\hline \multicolumn{5}{|c|}{$\begin{array}{l}\text { due to purchase or production over total assets. Standard error in parentheses. } \\
\text { a } \quad \Delta \text { nnsales is the first difference of the natural logarithm of total sales, lnsales to assets is the log of sales }\end{array}$} \\
\hline \multicolumn{5}{|c|}{ less the log of total assets, cash flow to assets is earnings after interest and taxes, but before depreciation } \\
\hline \multicolumn{5}{|c|}{ and dividends over total assets, $\Delta$ net working capital to assets is the first difference of net working capital } \\
\hline \multicolumn{5}{|c|}{ to total assets (where net working capital is defined as the sum of cash, inventories and short term claims } \\
\hline \multicolumn{5}{|c|}{ less short term debt), $\Delta$ long term debt to assets is the first difference of long term debt over total assets. } \\
\hline Variables are treated & entially endogenou & nd are instrumen & with their lagge & vels. \\
\hline
\end{tabular}




\section{Table 3}

The impact of cash flow on investment: uni-variate sample splits, 1992-1996

\begin{tabular}{|c|c|c|c|c|c|c|}
\hline \multirow{2}{*}{\multicolumn{2}{|c|}{ Independent variables ${ }^{\mathrm{a}}$}} & \multicolumn{2}{|c|}{ Retention class $^{\mathrm{b}}$} & \multicolumn{3}{|c|}{ Comovement ${ }^{\mathrm{c}}$} \\
\hline & & Low & High & Low & Medium & High \\
\hline \multirow{2}{*}{\multicolumn{2}{|c|}{$\Delta \ln$ Sales }} & -0.029 & -0.024 & -0.025 & -0.083 & -0.032 \\
\hline & & $(0.013)$ & $(0.015)$ & $(0.017)$ & $(0.027)$ & $(0.017)$ \\
\hline \multirow{2}{*}{\multicolumn{2}{|c|}{$\operatorname{lnSales~to~assets~}$}} & 0.060 & 0.057 & 0.083 & 0.071 & 0.023 \\
\hline & & $(0.015)$ & $(0.014)$ & $(0.019)$ & $(0.020)$ & $(0.013)$ \\
\hline \multirow{2}{*}{\multicolumn{2}{|c|}{ Cash flow to assets }} & -0.029 & 0.079 & -0.011 & 0.014 & 0.063 \\
\hline & & $(0.019)$ & $(0.032)$ & $(0.025)$ & $(0.032)$ & $(0.031)$ \\
\hline \multirow{2}{*}{\multicolumn{2}{|c|}{$\Delta$ Working capital to assets ${ }^{\mathrm{d}}$}} & -0.052 & -0.157 & -0.110 & -0.039 & -0.156 \\
\hline & & $(0.034)$ & $(0.064)$ & $(0.048)$ & $(0.072)$ & $(0.069)$ \\
\hline \multirow{2}{*}{\multicolumn{2}{|c|}{$\Delta$ Long term debt to assets ${ }^{\mathrm{d}}$}} & 0.100 & 0.256 & 0.151 & 0.191 & 0.304 \\
\hline & & $(0.059)$ & $(0.069)$ & $(0.080)$ & $(0.078)$ & $(0.138)$ \\
\hline $\mathrm{N}$ & & 119 & 82 & 96 & 48 & 48 \\
\hline \multicolumn{7}{|c|}{$\begin{array}{l}\text { Notes: Within-2SLS estimates of investment equation. Dependent variable i } \\
\text { to purchase or production over total assets. Standard error in parentheses. }\end{array}$} \\
\hline \multicolumn{7}{|c|}{ a $\Delta$ lnsales is the first difference of the natural logarithm of total sales, lnsales to assets is the log of sales } \\
\hline \multicolumn{7}{|c|}{ less the log of total assets, cash flow to assets is earnings after interest and taxes, but before depreciation } \\
\hline \multicolumn{7}{|c|}{ and dividends over total assets, $\Delta$ net working capital to assets is the first difference of net working capital } \\
\hline \multicolumn{7}{|c|}{ to total assets (where net working capital is defined as the sum of cash, inventories and short term claims } \\
\hline \multicolumn{7}{|c|}{ less short term debt), $\Delta$ long term debt to assets is the first difference of long term debt over total assets. } \\
\hline \multirow[t]{2}{*}{ b } & \multicolumn{6}{|c|}{ Based on dividend payout. A firm is in the high retention class when the dividend payout rate does not } \\
\hline & \multicolumn{6}{|c|}{ exceed 10 percent for six years or more. A firm is in the low retention class otherwise. } \\
\hline \multirow[t]{3}{*}{ c } & \multicolumn{6}{|c|}{ Comovement is low when the correlation between firm and industry sales is 0.106 or lower (the median). } \\
\hline & \multicolumn{6}{|c|}{ Comovement is medium when this correlation is in between 0.106 and 0.363 (which captures the third } \\
\hline & quartile) and it is higl & $\mathrm{n}$ the correla & exceeds 0.3 & & & \\
\hline d & Variables are treated & tranty ent & us and are & mented wit & eir lagged le & \\
\hline
\end{tabular}




\section{Figure 1}

Financing constraints and regimes

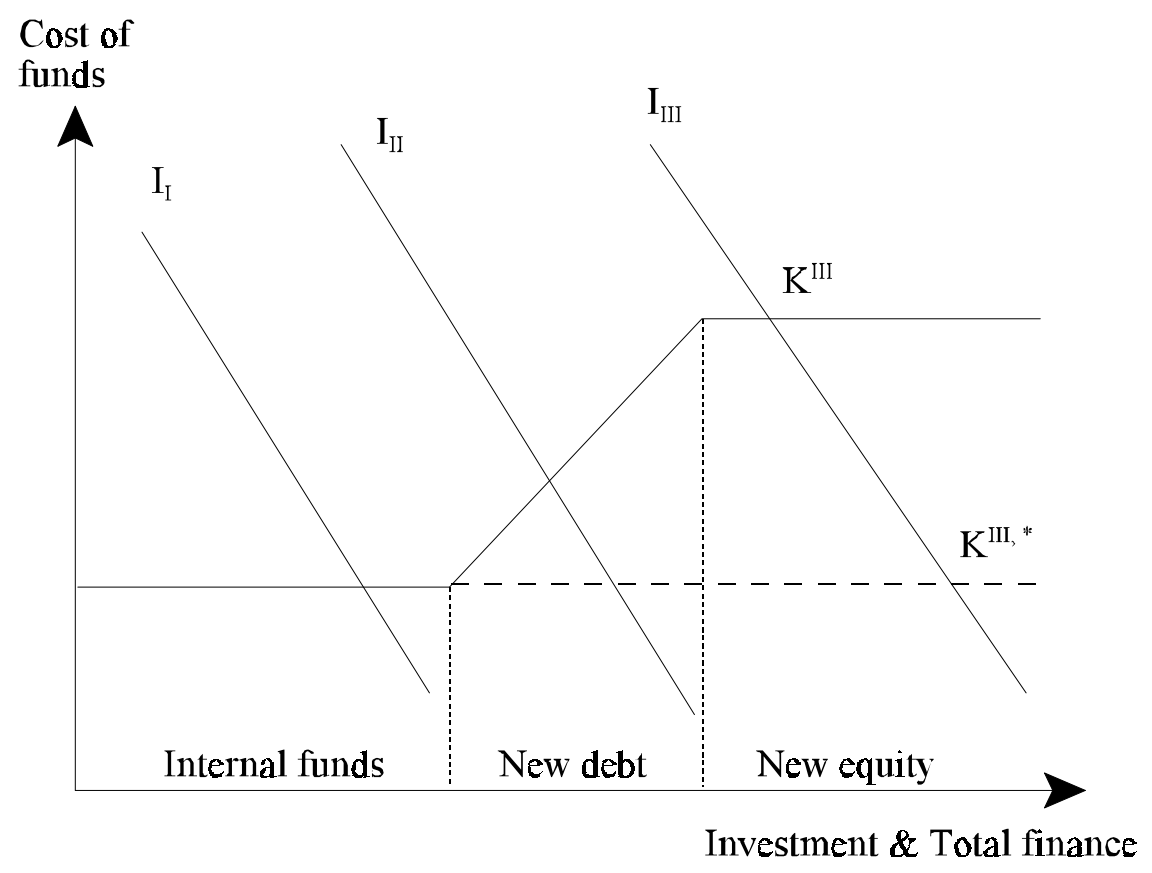

